The First Northern Ireland Peace Process 
This page intentionally left blank 


\section{The First Northern Ireland Peace Process}

Power-Sharing, Sunningdale and the IRA Ceasefires 1972-76

Thomas Hennessey

Professor of Modern British and Irish History, Canterbury Christ Church University, UK 


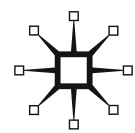

(C) Thomas Hennessey 2015

Softcover reprint of the hardcover 1st edition 2015 978-1-137-27716-9

All rights reserved. No reproduction, copy or transmission of this publication may be made without written permission.

No portion of this publication may be reproduced, copied or transmitted save with written permission or in accordance with the provisions of the Copyright, Designs and Patents Act 1988, or under the terms of any licence permitting limited copying issued by the Copyright Licensing Agency, Saffron House, 6-10 Kirby Street, London EC1N 8TS.

Any person who does any unauthorized act in relation to this publication may be liable to criminal prosecution and civil claims for damages.

The author has asserted his right to be identified as the author of this work in accordance with the Copyright, Designs and Patents Act 1988.

First published 2015 by

PALGRAVE MACMILLAN

Palgrave Macmillan in the UK is an imprint of Macmillan Publishers Limited, registered in England, company number 785998, of Houndmills, Basingstoke, Hampshire RG21 6XS.

Palgrave Macmillan in the US is a division of St Martin's Press LLC, 175 Fifth Avenue, New York, NY 10010.

Palgrave Macmillan is the global academic imprint of the above companies and has companies and representatives throughout the world.

Palgrave ${ }^{\circledR}$ and Macmillan ${ }^{\circledR}$ are registered trademarks in the United States, the United Kingdom, Europe and other countries.

ISBN 978-1-349-57549-7 ISBN 978-1-137-27717-6 (eBook)

DOI 10.1007/978-1-137-27717-6

This book is printed on paper suitable for recycling and made from fully managed and sustained forest sources. Logging, pulping and manufacturing processes are expected to conform to the environmental regulations of the country of origin.

A catalogue record for this book is available from the British Library.

Library of Congress Cataloging-in-Publication Data

Hennessey, Thomas.

The first Northern Ireland peace process : Power-Sharing, Sunningdale and the IRA Ceasefires 1972-76 / Thomas Hennessey (Professor of Modern British and Irish History, Canterbury Christ Church University, UK). pages $\mathrm{cm}$

1. Peace-building-Northern Ireland-History-20th century. 2. Northern Ireland-Politics and government-1969-1994. 3. Peace movementsNorthern Ireland-History-20th century. 4. Conflict managementPolitical aspects—Northern Ireland—History-20th century.

5. Counterinsurgency—Northern Ireland-History-20th century. 6. Irish Republican Army-History-20th century. 7. Great Britain-Foreign relations-Ireland. 8. Ireland-Foreign relations-Great Britain. I. Title. JZ5584.N75H46 2015

$941.60824-d c$

2015019253

Typeset by MPS Limited, Chennai, India. 
For Sam 
This page intentionally left blank 


\section{Contents}

Introduction

1 'Talking to Terrorists': British Government Contacts with the IRA 1972-74

2 Power-Sharing and the Council of Ireland: The Evolution of Irish and British Policy Strategies 1972-73

3 Power-Sharing

4 Sunningdale 111

5 A New Ceasefire: British and Republican Dialogue 1974-75 148

6 British-IRA Talks 1975-76 188

$\begin{array}{ll}\text { Conclusion } & 234\end{array}$

$\begin{array}{ll}\text { Notes } & 240\end{array}$

$\begin{array}{lr}\text { Bibliography } & 249\end{array}$

$\begin{array}{lr}\text { Index } & 252\end{array}$ 


\section{List of Abbreviations}

ASU Active Service Unit (of the IRA)

CDS Chief of the Defence Staff

CGS Chief of the General Staff

CLF Commander Land Forces

DFA Department of Foreign Affairs

DUP Democratic Unionist Party

EEC European Economic Communities

FCO Foreign and Commonwealth Office

GFA 'Good Friday Agreement', the 1998 Belfast Agreement

GOC General Officer Commanding

HMG Her Majesty's Government

HQNI (British Army) Headquarters Northern Ireland

IDU (The Irish Government's) Inter Departmental Unit on the North of Ireland

INLA Irish National Liberation Army

IRSP Irish Republican Socialist Party

JP Justice of the Peace

LAW Loyalist Association of Workers

MI5 Security Service

NILP Northern Ireland Labour Party

NIO Northern Ireland Office

OC Officer Commanding

PAC Provisional Army Council

PIRA Provisional Irish Republican Army

PR Proportional representation

RA Royal Artillery

RM Republican Movement

RUC Royal Ulster Constabulary

SDLP Social Democratic and Labour Party 
SIS Secret Intelligence Service (MI6)

SSNI Secretary of State for Northern Ireland

TD Teachta Dála (Dáil Deputy)

UDA Ulster Defence Association

UDI Unilateral Declaration of Independence

UDR Ulster Defence Regiment

UUC Ulster Unionist Council

UUP Ulster Unionist Party

UUUC United Ulster Unionist Council

UVF Ulster Volunteer Force

UWC Ulster Workers' Council 